\title{
Concept of Revenue, Expenses and Liabilities in Accounting for Zakat, Waqf and Baitulmal in Malaysia: An Analysis from Shariah Perspective
}

\author{
Marina Abu Bakar
}

Sultan Abdul Halim Mu’adzam Shah International Islamic University (UniSHAMS)

\begin{abstract}
Revenue, expenses and liabilities are an important concept in current accounting practices. These concepts are applied in accounting standards where this standard serves as a guideline for a company or organization in preparing and presenting income, expenses, assets and liabilities in accordance with the standards set by the International Accounting Standards Board (IASB). The accounting standards issued by this international body refer to conventional accounting standards. In Malaysia, the State Islamic Religious Council (MAIN) as the trustee for Zakat, Waqf and Baitulmal uses standards issued by the Malaysian Accounting Standards Board, Private Entity Reporting Standards (PERS) and best practice guidelines by the National Audit Department (Malaysia) (JANM). These two documents are used as references in the preparation of financial reporting for MAIN. However, there are problems in terms of implementing these concepts for Zakat, Waqf and Baitulmal with current accounting standards. This is because current accounting practices are different from the concepts of revenue, expenses and liabilities adopted by Zakat, Waqf and Baitulmal according to Islamic law. This study aims to analyze the concept of revenue, expenses and liabilities in Zakat, Waqf and Baitulmal accounting from Shariah perspective. The design of this study is qualitative. The method of content analysis was used to analyze data from sources such as classical Figh books. The findings show that there is a difference between the concept of revenue, expenses and liabilities in Zakat, Waqf and Baitulmal accounting in the Islamic context. The study is expected to help the parties involved to develop accounting standards for zakat, waqf and baitulmal which are compliant with Shariah.
\end{abstract}

Keywords: Islamic accounting standards, Zakat, Waqf, Baitulmal

\section{INTRODUCTION}

The Malaysian Constitution, clause 3 (4) states that Islam is under the jurisdiction of the Sultan and the King for the monarchy and under the authority of the King of the States for the non-monarchical states, such as Malacca, Penang, Sabah, Sarawak and the Federal Territory. This religious affair is contained in the Ninth Schedule of the Malaysian Constitution. Among them is Zakat, Waqf and Baitulmal (Azizah Dollah, 2012). By implication, the State Islamic Religious Council (MAIN) in each state is responsible for managing zakat, waqf and baitulmal matters in Malaysia and this includes the accounting aspects of the three entities. Accounting or in Arabic Al-muhasabah, is a process involving recording activities, classifying, analyzing and interpreting trading activities in a logical form or in accordance with the purpose of providing financial information before making a decision (Mohd Abdullah Jusoh \& Hazianti Abdul Halim, 2009). In summary, the accounting for zakat, waqf and baitulmal is the measurement, disclosure or the provision of certainty about the information that helps the MAIN to decide on the allocation of resources for the three entities. In the Islamic economic system, a Shariah-based accounting system 
must have a scope that not only affords its organization, but also takes into account the interests of the general public. Basically, this accounting system is responsible for the community and because of the ethics of society influenced by the Shariah demands, then monitoring the activities of the organization so that it is in harmony with Islamic law is an important responsibility. Each of these activities should be measured in terms of law (halal-haram continuum) and any sharia contradictory measures have no value (Mohd. Khir Ashari, 1991).

Some accounting theorists feel that Western accounting adopt narrow marginalization, utilitarian economic principles and assumes liberal democracy as the basis of society (Lehman, 1992). On the other hand, Islamic accounting can be regarded as a comprehensive accounting process for providing appropriate information, which is not limited to financial data to stakeholders in an entity only. In fact, the application of the Islamic accounting system will ensure that stakeholders in a moving entity continuously within the limits of Islamic law and at the same time, can achieve the socioeconomic objectives of the entity (Bala Shanmugam \& Vignesen Perumal, 2005). Among the objectives of Shariah accounting is to produce human beings who have the principle of Tauhid and obey the provisions of Allah. Therefore, the development of values of truth, honesty and justice must be practiced in Islamic accounting. As an implication, generally accepted accounting measures (standards) can only be implemented as long as it does not conflict with Islamic law (Abdullah Said \& Normala, 2011). In summary, the comparison between conventional accounting and Islamic accounting can be illustrated as follows in Table 1.

Table 1. Similarities and Differences Between Conventional Accounting and Islamic Accounting

\begin{tabular}{|c|c|c|}
\hline Element & $\begin{array}{l}\text { Anglo-American Accounting } \\
\text { Model }\end{array}$ & $\begin{array}{c}\text { Islamic Accounting } \\
\text { Model } \\
\end{array}$ \\
\hline Economic approach & Micro & Macro \\
\hline Society-based main user & $\begin{array}{l}\text { Investors and accounting policy } \\
\text { lenders }\end{array}$ & $\begin{array}{l}\text { Country, Management, } \\
\text { Objectives-oriented }\end{array}$ \\
\hline Asset Assessment & Previous Cost Price & Current Price \\
\hline Income Determination & Revenue-Expenses approach & $\begin{array}{l}\text { Asset-Liability } \\
\text { Approach }\end{array}$ \\
\hline Time value of money & Yes & No \\
\hline Time Frame & Yes & Yes \\
\hline Main Focus & Income Statement & Balance Sheet \\
\hline Theoretical Concepts & Entity Theory & Theory of Ownership \\
\hline Accounting postulates (assumptions) & Based on Income & Based on Shariah Law \\
\hline Fixed Interest & Yes & No \\
\hline Legal Orientation & Common Law & Shariah Law \\
\hline Accounting Ethics & Professional Ethics & Religious Ethics \\
\hline Stock Exchange Market & Yes & Yes \\
\hline Bon & Yes & Yes, on condition \\
\hline Accounting Approach & Value Approach & Events Approach \\
\hline Business dichotomy and moral & Yes & No \\
\hline
\end{tabular}


Meanwhile, MAIN as a statutory body is subject to the PA Treasury Circular 3.1 regarding the applicable accounting standards. Hence, all the State Islamic Religious Council (MAIN) has adopted the Private Entity Reporting Standards (PERS) issued by the Malaysian Accounting Standards Board (MASB) in preparing the financial statements. However, these standards cannot meet the requirements for creating MAIN account and transaction reporting related to zakat, waqf and baitulmal accurately (Maliah, et al., 2016). This problem occurs because the concept of revenue, expenses and liabilities implemented are different from the concepts adopted by zakat, waqf and baitulmal according to Islamic law. Therefore, this article attempts to analyze the concept of revenue, expenses and liabilities in accounting for zakat, waqf and baitulmal from Shariah perspective to assist in the development of accounting standards for Shariah-compliant zakat, waqf and baitulmal.

\section{CONCEPT OF REVENUE, EXPENSES AND LIABILITIES IN ISLAM}

In general, there is no specific discussion about the concept of revenue, expenses and liabilities in Islam by the classical Muslim jurists. Discussions relating to the concept of revenue, expenses and liabilities are discussed separately in debates on property theory and the theory of ownership in Islam. Therefore, the theory of property and ownership in Islam should be clarified in order to understand the concept of revenue, expenses and liabilities in Islam.

\section{Discussion about the Theory of Property in Islam}

In terms of language, property or assets can be defined as items that are owned and controlled by a person, whether in the form of objects that can be touched (ain) or benefit. For example, property in the form of objects that can be touched (ain) is gold and animals. Whereas, the example of property in the form of benefits is dwelling in the house and riding on horses. Based on the definition of this property, it is understandable that any unmanageable items such as trees in the forest, fish in the water or birds in the air are not classified as property (Zaydan, 2001). From the point of the term, the jurists differed in the terms of property and divided into two groups. Muslim jurists apart from the Hanafi school expressed the opinion that property is a valuable item. If the item is damaged, then the person who spoils the item must pay compensation. Muslim jurists from the Hanafi school also expressed their opinion that the property is an object that can be controlled and taken advantage of them. According to them, property is also restricted to physical objects and substances that can be felt (tangible). Therefore, they asserted that rights and benefits are not considered as property, otherwise considered as ownership. This view conflicts with the view of other schools because they thought that the rights and benefits are considered as property. This is because the purpose of the property itself is not the substance, but the benefits of the property. This view of the jurists implies the laws of seizing, lease and inheritance. For example, in the case of seizing, if a person seizes the garment and uses it, then for a moment he returns the garment to his owner, he shall compensate his beneficial value to the garment according to the jurists other than the Hanafi school. On the other hand, according to the Hanafi school, he does not have to pay compensation for the garment unless the seized garment is a donated property (waqf) or an orphan's property (Wahbah al-Zuhayli, 2009).

In the meantime, assets in accounting term can be defined as any item that may benefit future economic benefits and potential services to an entity (FRS, 2010). Based on this definition, 
there are three important factors to be taken into account on the assets, namely; control factors need to be in the asset, the ownership issue does not take into account and the value of the asset must be measurable. Therefore, a person may not own the asset, but if he/she controls the asset, he/she owns the asset. Similarly, if the asset cannot be measured or evaluated, it will not be considered an asset. Assets can be divided into two types, namely current assets and non-current assets. Current assets are assets that can be converted into cash within a short period of time, usually a year or a period of accounting. For example, banks, cash, stocks, debtors, previous expenses, accrued revenue and others. Meanwhile, non-current assets are long-term assets that are used to run a business over a long period of time. For example, vehicles, machines and others. It is not intended for resale in the hope of gaining profit (not for business profits). The definition of assets in conventional terms differs from the definition of assets in Islam because Islam recognizes the ownership of the assets owned even if the ownership is imperfect. In fact, the concept of assets in Islam is broader and more general than the concept of assets in conventional accounting terms.

Revenue is anything derived from business activities that add value to assets through the sale of goods or services. FRS 118 defines revenue as a gross inflow of economic benefits over the accounting period from an entity's ordinary activity, namely increase in assets or decreases in liabilities resulting from the increased equity due to various factors other than new capital contributions (FRS, 2010). Easily, the money received or to be received in the future by the MAIN can be categorized as revenue. The revenue is divided into two, namely business operating revenue and non-business operating revenue. Business operating revenue is derived from the main business activities such as sales of goods, services, property rental and others. Non-business operating revenue is derived from matters unrelated to core business activities such as bank deposit interest, rental payments received, dividends received, profit from the sale of non-current assets.

MASB9 defines expenses as an outflow of assets or reduction in economic benefits in the management of a business. In simple terms, expenses are the cost of services or goods paid or to be paid by MAIN when conducting business with the purpose of obtaining revenue for a business. Business operating expenses are expenses involved in daily business operations such as general expenses, salaries, advertisements, paid rent, and others. Meanwhile, non-business operating expenses are expenses that are not associated with normal daily operation of the business, such as loan interest, loss on disposal of assets, loss from fire, theft and so on.

Liability is a business obligation or debt that must be settled by the creditors in accordance with the agreed agreement (MAFSB9). In simple terms, liability can be defined as business debt to be settled by the MAIN with money, goods, or services. There are two types of liability, namely; non-current liabilities (long-term liabilities) which are repayable loans over a long period of time (more than one accounting period) such as loans, collateral loans, debenture mortgages and so on. Current liabilities (short term liabilities), which are repayable in a short period of time (less than one year) such as bank overdraft, accrued expenses, previous revenue, creditors and others. The owner's equity is the owner's investment in the business. In this context, business liabilities to owners is the amount of capital invested by the owners in the business and profits derived from business activities. Profit will increase the owner's equity, while losses and withdrawals will reduce the owner's equity. 


\section{Discussion about the Theory of Ownership in Islam}

The word of origin is derived from the word al-milk, which means the relationship between man and property recognized by the Islamic law, in which the property is devoted to the man and with this recognition allow him to administer the property according to his will as long as it does not conflict with the Islamic law (Wahbah al-Zuhayli, 2009). Majalah al-Ahkam al-Adliyyah (Article 125) defines property as belonging to a person, whether it is a form of goods (ain) or benefits. The word ownership also refers to something that is owned, for example, someone says "this stuff is mine", which carries the connotation of "mine". Based on this point, it can be concluded that the view of Hanafi's school on ownership is more general. They considered that the benefits and rights are owned, not property. Thus, according to the Hanafi school, ownership is more common than property (Md. Akhir, 1994).

In reality, the property can be owned. However, in some cases, there is a barrier in accordance with the Islamic law that causes it to not be given ownership. The Muslim jurists have divided the property into three categories; namely property that cannot be owned and cannot be received as a property devoted to the general benefits of the community, such as roads, bridges, rivers, railways, museums, public libraries and so on, property that can not be owned except by Islamic law such as waqf property and property of baitulmal and property which may be owned and given property, that is, other than two types of property mentioned (Zaydan, 2001).

The jurists also divide ownership, according to its kind. According to them, ownership is divided into two types, namely perfect ownership and imperfect ownership. Perfect ownership is the ownership of the substance and the benefits of a property. Among the features of the perfect ownership is absolute, without any limitation of time as long as the property remains, the owner is free to make transactions in his property such as using, increasing capital, investing, promoting, and administering the property according to his will. Imperfect ownership is the ownership of the property alone or the ownership of its benefits. Having benefited only known as haq al-intifa' (right to gain benefit). Having these benefits can be divided into two parts, namely; haq syakhsi (individual rights) and haq 'aini (property rights), which means the right to always follow the substance of the property, regardless of the person taking advantage of the property (Zaydan, 2001). Haq Irtifaq is the right set forth in immovable property for the benefit of other immovable property owned by others. This right is a perpetual right as long as the property remains without regard to its owners such as drinking rights, neighbors, rights to use the roads, the right to water and others (Wahbah al-Zuhayli, 2009). Among the characteristics of imperfect ownership is that it can accept the time limit, the place and the nature of it when it is implemented. This is contrary to the category of perfect ownership in Islam.

In Islam, one can possess the property (ain) only and at the same time the benefits of such property are owned by another person. For example, Ahmad expressed his desire to allow Ali to live in his home for three years. In this case, if Ahmad dies and Ali has received the will, then the house becomes the heir of inheritance and Ali can benefit during the prescribed period of three years. In this situation, the heirs are required to allow Ali staying in the house and if the heirs refuse to do so, Ali is entitled to make a legal claim (Zaydan, 2001). Similarly, in the ownership of the only benefits like Waqf. Waqf recipient or beneficiaries may benefit from Waqf properties and allow other individuals to use them on condition of obtaining permission from Waqf giver. 
There are some causes or reasons for the complete ownership, namely the mastery of something which is a must, through contract, or the replacement (khalfiah) and or through a child born of something that is owned (Wahbah al-Zuhayli, 2009).

\section{ZAKAT, WAQF AND BAITULMAL}

Zakat is included in the third pillar of Islam and is an obligation that has been established by the Islamic law and has a direct connection with the Islamic economic system. Zakat is one of the main pillars that serve as the basic factor in the distribution of wealth in the Islamic economy. Waqf is the practice of charity that is highly demanded by Islam. The power of waqf can be proved through a very important role in socioeconomic development of the Ummah which includes various aspects such as the Islamization of space, infrastructure development, eradication of poverty, health and others. Meanwhile, Baitulmal is a property and a financial institution that collects property owned by all the people who live and settle under the rule of the Islamic government. In summary, these three institutions work on the basis of the rules set out by the Islamic law.

In the context of Malaysia, Article 74 of the Federal Constitution places, religious affairs (including zakat, waqf and baitulmal) under the authority of the MAIN except for the Federal Territory of Kuala Lumpur, Labuan and Putrajaya as stipulated in the Ninth Schedule (Article $74,77)$ List 2 - List of States as follows:

\footnotetext{
"Except for the Federal Territory of Kuala Lumpur, Labuan and Putrajaya, Islamic law and personel and family law of persons professing the religion of Islam, including the Islamic law relating to succession, testate and intestate, betrothal, marriage, divorce, dower, maintenance,
}

\begin{abstract}
adoption, legitimacy, guardianship, gifts, pertitions and non-charitable trusts; waqf and the definition and regulation of charitable and religious trusts, the appointment of trustees and the incorporation of persons in respect of Islamic religious and charitable institutions opertaing wholly within the state; Malays customs; zakat, fitrah and Baitulmal or similar Islamic religious revenue; mosques or any Islamic public places of worship....."
\end{abstract}

The provisions in the Federal Constitution clearly state that MAIN has executive powers in relation to Islamic religious affairs and is a trusted institution for zakat, waqf and baitulmal in Malaysia.

\section{Zakat in Islam}

In terms of language, zakat means to grow and increase. Meanwhile, in terms of Shariah law, zakat is defined as the mandatory right on the property. The jurists have different views on the proposed definition of charity in accordance with Islamic law. The jusrits of the Shafi'i school says that zakat is a name for goods manufactured for property or body (human being for zakat fitrah) to certain parties. Meanwhile, the jurists of the Hanbali school give the definition of zakat as a mandatory right to certain property to a certain group at a certain time. The jurists of the Hanafi school assumed that zakat is the granting of a right of ownership over certain property to a certain person who has been determined by the Islamic law, solely for Allah. The jurists of the Maliki school also provide a definition of zakat, which is the process of removing certain part of the particular property that has reached nisab to the person entitled to receive, if the ownership, haul (enough one year) has been completed, in addition to minerals, 
crops and treasures. Based on the meaning of zakat submitted by the Muslim jurists, it is clear that zakat refers to the granting of zakat itself (granting the mandatory property rights) to the asnaf groups which have been determined by the Islamic law (Wahbah al-Zuhayli, 2009).

There are two types of obligatory zakat, namely zakat fitrah and zakat harta (zakat on property). Zakat fitrah is a mandatory payment for every Muslim individual from Ramadan to 1 Syawal. Zakat harta (zakat on property) is a mandatory payment when the property reaches the rate and period set by the Islamic law. The property which is subject to zakat is gold, silver, business, income, stock, money, savings, agriculture and minerals. The zakat rate varies according to fixed assets and property changes. For property changes, the rate of zakat charged is between $1.25 \%$ to $2.5 \%$. Meanwhile, for fixed assets, the rates charged are 5\%, 10\% and $20 \%$. The rate used in the calculation of zakat for business, savings and income is $2.5 \%$.

Zakah is distributed to eight groups of asnaf, namely the poor (fakir), needy (miskin), amil, ar-riqab (slave), algharimin (the indebted), fi sabilillah and ibn sabil. This is in line with the Quran, in Surah At-Taubah, verse 60 which means; "Zakat expenditures are only for the poor and for the needy and for those employed to collect zakat and for bringing hearts together (for Islam) and for freeing captives (or slaves) and for those in debt and for the cause of Allah and for the (stranded) traveller - an obligation (imposed) by Allah. And Allah is Knowing and Wise". The jurists have different interpretations of each group that are eligible for zakat.

Zakat accounting (Muhasabah alZakah) is a field of accounting knowledge to determine and assess the property of zakat, determine its rate, make the assessment of the zakat imposed, collect and distribute the zakat property that is collected to zakat recipients based on the rules prescribed by the Islamic law (Husain Sahatah, 2003). Zahri Hamat (2013) concludes that there are five phases involved in zakat accounting. The first phase, determining the assets that are obliged to pay zakat. The second phase, assessing the assets required to pay zakat. The third phase, determining the appropriate zakat rate. The fourth phase, distributing the zakat collection to the zakat recipients and the fifth phase, providing a report on the collection and distribution of zakat to the authorities.

From the perspective of accounting, zakat also has a standardized procedure beginning from the beginning of its obligations set by Islam. This procedure is fixed and unchanged except in the aspect of its implementation process. The basis of zakat accounting is enforced on a regular and comprehensive basis for all Muslims. Thus, the obligation of zakat continues to be a debt to Allah s.w.t if it is not implemented. In fact, this debt will not be eliminated only after death, until the heirs are required to settle the debt using the property of the deceased before distributing the property of the heir (faraid property). According to Ezani Yaakub (2011), the accounting principles of zakat can be summarized as follows:

1. The basis of valuation based on current price. This assessment should be carried out in accordance with the prescribed haul period and on the due date of the round of haul or the date of commencement of zakat calculated.

2. One year, according to the Islamic calendar (Qamariah) should be used for those subject to haul period. This is based on the hadith from Rasulullah s.a.w; "There is not Zakat on wealth until Haul (one year) has passed" (Ibn Majah).

3. Year of production. Everything must be calculated within the haul of the year only. Therefore, all production proceeds over the period of the zakat 
account for the relevant Qamariah year (Islamic calendar) need to be brought to the next year.

4. Based on nisab predetermined either 85 grams of gold (20 Dinars) or 595 grams of silver (200 Dirhams). It can then be valued with local currency according to the current value of gold or silver, livestock and agriculture. Nisab is in accordance with a predetermined formula.

5. Imposed on net income rather than gross income. Deductions on assets.

6. For zakat income, reasonable basic needs should be deducted according to current or local arrangements. The value or sum of the deductions will always change. The change policy is generally subject to the jurisdiction of a country.

The obligation of managing zakat is a trust that the manager has to carry out with full responsibility and integrity. Apart from collecting, zakat funds are also required to be distributed according to the rules set by Allah. The organization responsible for the zakat fund is obliged to issue them and distribute them to those entitled. From the aspect of the distribution of zakat funds, Allah has clearly stated it as a guideline to be followed by Muslims. The zakat funds donated by those who are qualified shall be distributed according to the eight groups of asnaf which have been determined by the Islamic law.

\section{Implementation of Zakat in Malaysia}

In Malaysia, zakat is included in the jurisdiction of state administration, which has the effect of establishing a separate zakat law for every state in Malaysia. The authority to administer zakat in each state is subject to the laws of the respective states. The zakat laws of each state are usually contained in the State Islamic Administration Enactment (EPAIN) and until 2018, only two states in Malaysia have the Special Enactment of Zakat, namely Kedah and Sabah. Among the matters listed in the zakat administration clauses are the fundamental system for the collection of zakat, zakat asnaf, the law for not paying zakat or the payment of zakat through unofficial channels (unless stated otherwise) and some other rules. Until now, there is no method or regulation in relation to the distribution of zakat (Hasan Baharom \& Ezani Yaakub, 2011).

There are several principles of zakat fund distribution in Islam. These principles are trust, isti'ab (zakat funds must be allocated to all eight assassinated groups and based on the priority policy decided by the body affected. The concept of transfer to other asnaf must refer to the needs and the excess of funds accumulated), ikhtisas (zakat funds must be allocated to eight recipients (asnaf) in their respective states), haq (zakat funds accumulated must be allocated immediately based on the current requirements to each asnaf in physical form or benefit), muraqabah (zakat funds distributed shall be monitored and controlled), kifayah (based on the principle of actual needs according to asnaf and their income does not exceed the limits of kifayah), fawran (the zakat manager should ensure that the names of the asnaf are accurate so that the distribution can be submitted immediately and to the actual asnaf), istiqlal (all zakat funds accumulated should be separated in separate accounts from other accounts), ihsa' (the appropriate distribution has been reviewed, monitored and certified by the acceptance of the distribution to asnaf), tarshih (zakat payers are required to nominate zakat recipients to amil), priority (each distribution must give priority to the poor, needy and amil before distributing to other asnaf) and tamlik (distribution of zakat funds conceptualizes ownership of each asnaf).

In summary, the distribution of zakat in Malaysia can be done through two methods. First, self-distribution; and second, productive distribution. Self- 
distribution is distributed in the form of monthly remuneration, special help in home rental payments or educational support. This type of help is aimed at helping the poor and needy survive to fulfill the basic needs. Whereas, productive distribution is distributed in the form of capital either human capital or business. Human capital assistance is provided in the form of skills training, while business capital in cash and equipment. Business capital assistance aims to help the poor and needy change their lives for the better, that is, from zakat recipients to zakat payers (Rosbi Abd. Rahman, Sanep Ahmad \& Hairunnizam Wahid, 2008).

Assistance given to each asnaf is different according to the state in Malaysia as the interpretation of these groups is different according to the fatwa in their respective states. For example, the definition of asnaf al-Riqab is different according to the State current fatwa. Penang, Perak, Malacca and Johor for example, decided not to distribute zakat to asnaf al-Riqab because the interpretation of al-Riqab definition made by fatwa in each state only restricts the liberation of slaves. However, there are states like Terengganu, Pahang, Negeri Sembilan, Selangor and Perlis, which expand the interpretation of asnaf al-Riqab by distributing zakat to eradicate ignorance, social problems and faith (Nur Anisah Nordin \& Wan Mohd Khairul Firdaus Wan Khairuldin, 2017).

\section{The Concept of Waqf in Islam}

The Waqf in Arabic is derived from Waqf, which means holding something. Holding something that is meant here is to hold a property solely because of Allah for public interest (Al-Ansari, t.t). There are various definitions of Waqf that have been raised by the Muslim jurists such as al-Qurtubi, al-Sharbini and Ibn Abidin. Imam alQurtubi said that the Waqf is to produce wealth and the benefits of belonging to a path blessed by Allah to get close to Him (Al-Qurtubi, 1980). Al-Sharbini stated that Waqf means holding a property or goods that can be utilized on the basis of its physical condition remains in accordance with the conditions permitted by the Islamic law (Al-Sharbini, 1933). Ibn Abidin explained that Waqf means to hold a property in accordance with the provisions of owner and used for the general benefit (Ibn Abidin, 1966). From the definitions of Waqf above, it can be concluded that the Waqf property in Islam must have seven specific features; namely the property to be devoted must be clear of its possession, it may be beneficial, not of the kind that is prohibited by the Islamic law, its permanent physical nature, cannot be used other than what is required, for the property of waqf which is not mentioned in use, it may be used in accordance with the requirements of Islamic law and revenue from waqf property may be used for general or specific benefits. Waqf is also an optional which is highly encouraged by Islam.

Pillars of Waqf are divided into four, namely; Waqf giver, Waqf property, Waqf recipient and offer and acceptance of Waqf (sighah) (Mustofa al-Khin, et al, 2003). The jurists have divided the Waqf into three main types, namely; in terms of acceptance, purpose and time. In terms of acceptance, Waqf can be divided into two; special Waqf and general Waqf (Wahbah al-Zuhayli, 2009). The special Waqf is an endowment that has clearly defined the recipients, whether to a particular individual, group or institution. This type of Waqf gives property ownership to the beneficiary, and only those who are entitled to manage, use and benefit from it. General Waqf is an endowment that does not define the recipients clearly, but refers to the welfare of the Ummah in general. This type of Waqf does not require the element of acceptance in Islamic law, but Allah is the owner of the property donated in this context. This Waqf is also managed by the Sultan or the government, while its 
benefits are channeled to virtue in general. In terms of purpose, Waqf can be divided into three; namely Charitable Waqf, family Waqf and joint Waqf (Abu Zahrah, 1971). Charitable Waqf is performed because of Allah and the welfare of mankind. Family Waqf is an endowment dedicated to ourselves and family only. Meanwhile, the joint Waqf is associated with charitable Waqf and family Waqf. For example, Azman is a Waqf giver, donated his property for charity with a sum of RM $1,000.00$ and the balance is given to his family members. In terms of time, Waqf is divided into two types; temporary Waqf and permanent Waqf (Abu Zahrah, 1971). Temporary Waqf is a restricted endowment, which is limited by time, such as for two years. After this period, it is no longer regarded as a Waqf property. Permanent Waqf is an endowment made eternally without time, which can be classified as a ceaseless charity (Sadaqah jariah) which will render rewards to the Waqf giver continously until the donated property is destroyed or unusable.

In terms of ownership of Waqf property, the jurists are divided into two groups. The first group consisted of the Hanafi and Maliki jurists. They assumed that the Waqf property remained the property of the Waqf giver. According to them, Waqf equated with loans, rather than grants or gifts. Therefore, Waqf recipient only gains benefits. They also pointed out that the Waqf giver is the most qualified person to manage Waqf and managementrelated tasks should not be given to others. The views of the second group are different from the first group. The second group was pioneered by the Shafi'i and Hambali jurists. They stated that the property of Waqf is transferred to the Waqf recipient (beneficiary). According to them, the Waqf is the transfer of property from the Waqf giver to the beneficiary. This is equivalent to a gift or grant, in which the Waqf giver no longer has the power over the property that has been assigned to the beneficiary. However, all the jurists agree that all the property Waqf cannot be sold, rewarded, given to others or inherited as long as it is still regarded as a Waqf property.

Based on the concept of Waqf in Islam, it is understood that the Waqf whether it is general or special, it actually belongs to Allah absolutely. Pursuant to this principle, Waqf property cannot be sold, bought, made as a gift or inheritance either by a Waqf giver or a Waqf recipient/beneficiary. Therefore, the use of this Waqf property is left to the beneficiaries and is managed in accordance with the requirements of Waqf giver.

\section{Implementation of Waqf in Malaysia}

Like zakat, Waqf is also included in the affairs of Islam under the jurisdiction of the state government. Provisions on Waqf are found in EPAIN and until 2018, only five states in Malaysia have the Special Enactment of Waqf, namely Selangor, Malacca, Negeri Sembilan, Perak and Terengganu. All provisions in EPAIN and the Special Enactment of Waqf clearly state that MAIN is the sole holder of all types of Waqf assets. This means that the other parties are not allowed to handle the management of the Waqf. Among the provisions that are associated with waqf are MAIN as the sole trustee of waqf property, the distribution of waqf property to the special waqf and general waqf, the benefit of the special waqf is to meet the special waqf purposes only, the benefits of general waqf can be used for purposes that do not conflict with Islamic law, all the property to be donated must be permanent, beneficial in accordance with Islamic law and irrevocable, the acquisition of property must be permanent, the purpose of waqf must be on the required matters, prohibition to endow more than $1 / 3$ of the property owned and the records of the waqf property shall be kept by the MAIN (Baharuddin Sayin, Asmak Hj. Ali \& S. Salahuddin Suyurno, 2006). 
In managing Waqf, MAIN plays the role to manage all Waqf applications made by individuals or organizations covering special and general Waqf, recording and registering all types of Waqf properties, regulating all types of Waqf properties and developing Waqf properties, especially the Waqf properties categorized as general Waqf. In terms of practice, there are various forms of Waqf implemented in Malaysia such as property Waqf, cash Waqf, stock Waqf, feet Waqf, Takaful Waqf plan and so on.

\section{The concept of Baitulmal in Islam}

Baitulmal can be defined as a national treasury based on the history of Islamic rule (Ibn Taimiyyah, 1992). During the reign of the Prophet s.a.w, the role of baitulmal as an institution was less prominent. Among the factors that happens is because of Islam was still underdeveloped and not widely spread. The income and management of the country were also not complicated and complex. At this time, the country's source of income consists of the spoils of war or through a peace treaty. Zakat collection was then distributed to the asnaf. This situation continued until the reign of Caliph Abu Bakr Al-Siddiq r.a (Hailani Muji Tahir, 1988). In the 13th year of Hijrah, during the reign of Khalifah Umar Al-Khattab r.a, a department (diwan) named Baitulmal has been established to manage the state treasury. The treasury (Baitulmal) was established in Medina and in the territories under the rule of the government. The Central Government of Medina has placed several special officers in the territories under the jurisdiction of the Islamic government. All these officers were under the direction of the Central Government (Muhammad Sabri Haron, 2003). After the reign of the four Khalifah, the management of baitulmal became increasingly systematic. This is because the source of baitulmal property is increasing along with the increase of territories under the Islamic government. Historically, baitulmal property has reached 900 million Dirhams during the Abbasid dynasty under the rule of the Caliph Harun al-Rasyid (Hailani Muji Tahir, 1988).

Baitulmal accepts certain sources, which are not limited to only Muslim societies, even including non-Muslims (Muhammad Kamal 'Atiyah, 1993). The sources of baitulmal consist of the collection of kharaj, jizyah, fai', ghanimah and 'usyur. Kharaj was a certain payment collected from crops cultivated by the disbelievers (Musyrikin). Fai' was a collection of crops from land given by disbelievers to Muslims as a result of the peace treaty. Ghanimah refers to war spoils obtained from the disbelievers. Jizyah is an individual tax imposed on non-Muslims. Menawhile, 'usyur was a $10 \%$ fee imposed on merchandise belonging to non-Muslims who came to do business in Islamic countries. For ahl zimmah, the goods tax charged was 5\%. In addition to these sources, baitulmal also receives income from zakat collection, inheritance without heirs and property of unknown owners. However, the function and role of baitulmal have changed to be smaller and limited after the Crusades (1096-1258M) occurred, where the majority of Muslim countries were conquered by Western powers (Mustafa Daud, 1994). Based on the history of baitulmal, a formula can be made, namely the source of income for baitulmal is totally and infinite from the Muslim community, even covering payments from non-Muslims. This was in line with the broad scope and role of baitulmal as the state treasury.

The baitulmal concept can also be seen through the examples of Al-Mawardi, Abu Ya'la, Ibn Taimiyyah and Greg Zaidan. Al-Mawardi has divided public power in Islamic rule into various divisions, including finances and expenses. Among the financial resources were zakat, fai', ghanimah, jizyah and kharaj. 
Meanwhile, military and civil services were included in the aspect of expenses. In debating about baitulmal, he has elaborated baitulmal financial resources consisting of zakat, fai', ghanimah, jizyah, kharaj and property of unknown owners. In the aspect of baitulmal expenses, AlMawardi asserted that baitulmal was obliged to spend its wealth for anything that benefits (maslahah) to the general Muslim community (Al-Mawardi, 1978). This view seems to coincide with the views of Abu Ya'la where he agreed with the views quoted by Al-Mawardi related to the resources and baitulmal expenses (Abu Ya'la al-Farra', 1983). In addition, Ibn Taimiyyah also talked about the concept of baitulmal in his writing entitled Al-Siyasah al-Syar'iyah fi Islahi al-Ra'i wa al-Ra'iyah. According to him, there are three types of property mentioned in the Qur'an and Sunnah as a public property, namely zakat, ghanimah and fa' $i$ (Ibn Taimiyyah, 1983). Greg Zaidan classifies baitulmal as a group of government property that serves to collect all state property from various sources and spend it according to the interests of the Muslims (Greg Zaidan, t.t). Based on these views, it is clear that baitulmal is the national treasury according to the perspective of law and the administration of the Islamic country. The resources were like zakat, fai', ghanimah, jizyah, kharaj and property of unknown owners. In terms of its sources and expenses, it is flexible and it can be spent on anything that leads to goodness towards the Muslim community in general.

\section{The implementation of Baitulmal in Malaysia}

Today, the existing Baitulmal is not the national treasury of the true concept. In the context of practice in Malaysia, it can be regarded as a unit or department in the administration of the State Islamic Religious Council (MAIN). Today, the existing Baitulmal is not the national treasury of the true concept. In the context of practice in Malaysia, it can be regarded as a unit or department in the administration of the State Islamic Religious Council. Baitulmal is also not the treasury of the MAIN itself, but is categorized as the Special Fund of the Council. The council acts as a manager in managing baitulmal administration in a state. In terms of its source of income, baitulmal receives resources from unreasonable heritage property, Waqf properties, vows and goods found (luqatah), even zakat itself excluded because the fatwa in Malaysia has determined that the distribution of zakat and baitulmal cannot be united (Zakariah Abdul Rashid, 2003). Zakat is also not a baitulmal financial source because zakat is specifically spent on certain asnaf only, except where there is a surplus of zakat. Nonetheless, there are a variety of different fatwas regarding surplus of zakat among jurists, which some consider that this surplus can be put into treasury, some do not allow it and some of them categorize it as the dependent money (tawaqquf) (Mahmood Zuhdi Abdul Majid, 2009).

Each MAIN in Malaysia has provisions on the role of baitulmal in the State Islamic Administration Enactment (EPAIN) respectively. In general, baitulmal managers are responsible for managing baitulmal on the basis of trust. All types of assistance derived from baitulmal resources are intended to help and not intended to generate profit (Hailani Muji Tahir \& Sanep Ahmad, 2009). The practice of baitulmal is different between the states in Malaysia such as the assistance for admission to the Institute of Higher Education, general assistance for Muallaf, assistance to be channeled to the Islamic Religious School, poor and needy livelihood assistance, assistance to further studies in the Middle East and so on. 


\section{ANALYSIS AND DISCUSSION}

In conclusion, there are three funds under the management of MAIN, namely Zakat, Waqf and Baitulmal. These three funds can be categorized as trust that must be managed by MAIN efficiently. This is in line with the concept of trust in accordance with the Islamic law and anything contained in the Federal Constitution, which provides MAIN as a trustee in matters or affairs related to the Islam, including Zakat, Waqf and Baitulmal.

Nevertheless, if reviewed the interpretation of the trust in detail, it is found that MAIN is the trustee of zakat and Waqf property, but for baitulmal property, it is fully owned by MAIN. In the context of baitulmal, MAIN acquired the source from one of the divisions of zakat asnaf, namely amil. Hence, MAIN has full power to manage and spend baitulmal property according to the Islamic law. Trust in the context of this baitulmal property is only in small circles when compared to the concept of trust in zakat and Waqf property. MAIN only needs to spend baitulmal property according to the benefit of Muslims as a whole. In accounting, this baitulmal property belongs to MAIN and is classified as a revenue.

This is in contrast to Zakat and Waqf, where the concept of trust is more binding on the role of the State Islamic Religious Council (MAIN). MAIN is responsible for spending zakat revenue, according to the division of seven asnaf as required by the Islamic law. Although the mandate allocated to MAIN in the distribution of zakat to seven asnaf is the same, but the interpretation of each of these asnaf groups varies according to the state, respectively. In accounting, zakat revenue is a trust on behalf of MAIN to be spent on the seven asnaf groups and classified as liabilities.

For Waqf, it is necessary to look at the types of Waqf. MAIN as the sole trustee of Waqf property is responsible for managing all types of Waqf and this includes general Waqf and special Waqf. For special Waqf, MAIN is required to manage the Waqf according to the recipient as clearly stated by the Waqf giver. In special Waqf, the Waqf becomes the beneficiary's property and they are entitled to manage, use it and gain benefit. In accounting, this special wakaf is a trust on behalf of MAIN to be expended on the recipient and classified as a liability. Whereas, for general Waqf, it is more common for the welfare of the Muslim community because this type of waqf does not clearly identify the recipients. This type of waqf is not necessary to the element of acceptance, but it will continue to be Allah's property. This Waqf will be controlled by the government and its benefits will be channeled to virtue in general. In accounting, general Waqf is a trust on behalf of MAIN to be spent on charity and classified as revenue or equity. However, equity in the context of general Waqf is limited equity as it is still a trust that must be carried out by MAIN. In terms of ownership, there are no issues arising because of the Hanafi jurists still recognize imperfect ownership in Islam.

\section{CONCLUSION}

In developing Islamic accounting standards for zakat, waqf and baitulmal in Malaysia, there are various accounting aspects to consider. This aspect includes the concept of revenue, expenses and liabilities that are applied must comply with the requirements of Islamic law. Implementation of Islamic accounting standards becomes more complex and focused on MAIN because of the legislative constraints inherent in the Federal Constitution, which it has to meet the requirements of all MAINs throughout Malaysia. The implementation of the Islamic accounting standards for zakat, waqf and baitulmal in Malaysia demonstrates the proactive efforts of the 
Accountant General's Department of Malaysia (AGD) in reviewing and reviewing the requirements of Shariahcompliant accounting standards for Islamic institutions in Malaysia.

\section{ACKNOWLEDGEMENT}

This article is part of the findings of the Islamic Accounting Standards on Development Projects for Zakat, Waqf and Baitulmal Institutions in Malaysia by the Accountant General 's Department of Malaysia (AGD). The high esteem is given to researchers from the Tunku Puteri Intan Safinaz Accounting Center, College of Business, Universiti Utara Malaysia, Sintok for inviting writer as a speaker for the expert consultation program in this research project.

\section{REFERENCES}

Abdullah Said \& Normala Rabu. (2011). Konsep dan Sejarah Perkembangan Ilmu Perakaunan dalam Islam dlm Beberapa Aspek Asas Perakaunan Islam, pnyt. Mahbob Mahfot. Shah Alam: Pusat Penerbitan Universiti (UPENA) Universiti Teknologi MARA.

Abu Ya'la al-Farra'. (1983). Al-Ahkam alSultaniyyah. Beirut: Maktabah alHayat.

Abu Zahrah, Muhammad. (1971). Muhadarat fi al-Waqf. Kaherah: Dar al-Fikr al-'Arabi.

Al-Ansari, Jamal al-Din Muhammad ibn Mukram. (t.t). Lisan al-Arab. Mesir: Dar al-Masriyah.

Al-Mawardi. (1978). Al-Ahkam alSultaniyah wa al-Wilayat alDiniyah. Beirut: Dar al-Kutb al'Ilmiyyah.

Al-Qurtubi, Yusuf Ibn Abdullah. (1980). Kitab al-Kafi fi Ahl al-Madinah alMaliki. Juz 2. Riyadh: Maktabah al-Riyadh al-Hadithah.
Al-Sharbini, Muhammad Ibn Ahmad. (1933). Mughni al-Muhtaj. Juz 2. Mesir: Mustafa al-Babi al-Halabi.

Azizah Dollah. (2012). Zakat dan Cukai di Malaysia (Praktis Mudah Pembayar Zakat dan Cukai Individu). Shah Alam: Penerbit Press Universiti Teknologi MARA.

Baharuddin Sayin, Asmak Hj. Ali \& S. Salahudin Suyurno. (2006). Pengenalan kepada Konsep Wakaf dalam Islam. Shah Alam: Penerbit Press Universiti Teknologi MARA.

Bala Shanmugam \& Vignesen Perumal. (2005). The Need for Islamic Accounting dlm Issues in Islamic Accounting, pnyt. Bala Shanmugam, Vignesen Perumal \& Alfieya Hanuum Ridzwa. Serdang: Universiti Putra Malaysia.

Ezani Yaakob. (2011). Perakaunan Zakat $\mathrm{dlm}$ Beberapa Aspek Asas Perakaunan Islam, pnyt. Mahbob Mahfot. Shah Alam: Pusat Penerbitan Universiti (UPENA) Universiti Teknologi MARA.

Greg Zaidan. (t.t). Tarikh al-Tamadun alIslami. Beirut: Maktabah al-Hayat.

Hailani Muji Tahir. (1988). Pengenalan Tamadun Islam dalam Institusi Kewangan. Kuala Lumpur: Dewan Bahasa \& Pustaka.

Hailani Muji Tahir \& Sanep Ahmad (2009). Aplikasi Fiqh Muamalat dalam Sistem Kewangan Islam. Shah Alam: Pusat Penerbitan Universiti (UPENA) Universiti Teknologi MARA.

Hasan Baharom \& Ezani Yaakub. (2011). Pengurusan Zakat Semasa. Shah Alam: Pusat Penerbitan Universiti (UPENA) Universiti Teknologi MARA.

Husain Shahatah. (2003). Kaedah Agihan Zakat Harta, Pengertian, Sistem dan Agihannya. Diterjemah oleh Hamid Fahmy Zarkasyi dan Harun Ar-Rashid Hj. Tuskan. Kuala Lumpur: Pustaka Al-Shafa. 
Ibn Abidin, Muhammad ibn 'Amin. (1966). Hashiah Radd al-Mukhtar. Juz 4. Mesir: Mustafa al-Babi alHalabi.

Ibn Taimiyyah. (1983). Al-Siayasah alSyar'iyyah fi Islahi al-Ra'I wa alRa'iyah. Kaherah: Matba'ah Salafiyah.

Ibn Taimiyyah. (1992). Al-Siayasah alSyar'iyyah. Kaherah: Maktabah Salafiyah.

Lehman, C. (1992). Accounting's Changing Role in Social Conflict. London: Paul Chapman Publishing. Mahmood Zuhdi Abdul Majid. (2009). Pentafsiran Semula: Sumber Baitulmal dlm Prosiding Konvensyen Baitulmal

Kebangsaan 2009, pnyt. Sohaimi Mohd Salleh, Rokhoun Nafsiah Abd. Rashid \& Hasan Hafizi Hanapi. Putrajaya: Jabatan Wakaf, Zakat dan Haji (JAWHAR).

Malaysian Accounting Standard Board (MASB). (1997). Standard 9. Kuala Lumpur: Malaysian Accounting Standards Board.

Md. Akhir Hj. Yaakob (pntj.). (1994). AlAhkam al-Adliyyah. Kuala Lumpur: Dewan Bahasa \& Pustaka.

Mohd Abdullah Jusoh \& Hazianti Abdul Halim. (2009). Pengauditan. Kuala Lumpur: CERT Publication.

Mohd. Khir Ashaari. (1991). Perakaunan dlm Pengurusan Perniagaan Islam, pnyt. Sheikh Ghazali Sheikh Abod \& Zambry Abdul Kadir. Shah Alam: HIZBI.

Muhammad Kamal 'Atiyah. (1993). Sistem Perakaunan dalam Islam. Kuala Lumpur: Dewan Bahasa \& Pustaka.

Muhammad Sabri Haron. (2003). InstitusiInstitusi Kewangan Islam dalam Tamadun Islam dan Kenegaraan Malaysia. Bangi: Universiti Kebangsaan Malaysia.
Mustafa Daud. (1994). Tamadun Islam. Kuala Lumpur: Utusan Publications.

Mustofa al-Khin, Mustofa al-Bugha \& Ali al-Syarbaji. (2003). Kitab Fikah Mazhab Syafie. Terj. Solehan Ayub. Kuala Lumpur: Pustaka Salam.

Nur Anisah Nordin \& Wan Mohd Khairul Firdaus Wan Khairuldin. (2017). Kedudukan dan Pengagihan Zakat Asnaf Al-Riqab di Institusi-Institusi Zakat Malaysia dlm Isu-Isu Kontemporari dalam Zakat, Wakaf dan Filantropi Islam, editor Najahuddin Lateh, Muhamad Rahimi Osman \& Ghafarullahuddin Din. Shah Alam: Akademi Pengajian Islam Kontemporari (ACIS) Universiti Teknologi MARA.

Rosbi Abd. Rahman, Sanep Ahmad \& Hairunnizam Wahid. (2008). Pelaksanaan Bantuan Modal Zakat: Analisis Perbandingan dlm Prosiding Seminar Kebangsaan Ekonomi Malaysia 2008. Bangi: Universiti Kebangsaan Malaysia.

Sulaiman, M., Mohamad, M. H. S., Rashid, H. M. A., Osman, A. Z., Siraj, S. A., \& Nuhu, I. (2016). Accounting and Accountability of Waqf, Zakat and Baitulmal (WZB) in Malaysia: A Review Literature. IPN Journal of Research and Practice in Public Sector Accounting and Management, 6.

Taheri, M.R. (2003). The basic principles of Islamic economy and their affects on accounting standardssetting. $\quad \mathrm{http}: / /$ islamic-financenet/islamic-accounting/acctg6.html. Wahbah al-Zuhayli. (2009). Al-Figh alIslami wa Adillatuh. Jil 3, 6 \& 10. Beirut: Dar al-Fikr.

Zahri Hamat. (2013). Perakaunan Zakat Perniagaan di Malaysia. Kuala Lumpur: Dewan Bahasa \& Pustaka. 
Zakariah Abdul Rashid. (2003). Baitulmal:

Konsep Asal dan Amalan Masa Kini, dlm Ke Arah Pembangunan Baitulmal Kebangsaan, pnyt. Nik Mustapha Hj. Nik Hasan. Kuala Lumpur: Institut Kefahaman Islam Malaysia (IKIM).

Zaydan, Abdul Karim. (2001). Al-Madkhal li Dirasah al-Syariah alIslamiyyah. Damshiq: Dar alRisalah.
Marina Abu Bakar Sultan Abdul Halim Mu'adzam Shah International Islamic University (UniSHAMS)

Malaysia 